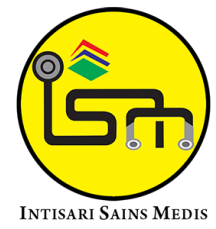

Published by Intisari Sains Medis

\section{Hubungan indeks platelet dengan derajat keparahan penyakit demam berdarah dengue pada anak di RSUD Wangaya}

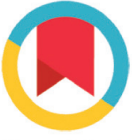

CrossMark

\author{
Valerie Michaela Wilhelmina ${ }^{1 *}$, I Wayan Bikin Suryawan ${ }^{2}$, Kadek Suarca ${ }^{2}$
}

\section{ABSTRACT}

Background: Indonesia is an endemic country for Dengue Hemorrhagic Fever (DHF). Over $80 \%$ of children at age $\geq 10$ in Indonesia have been infected with dengue at least once. Dengue shock syndrome (DSS), as a severe clinical manifestation of DHF, has a high risk of mortality. The wide spectrum of dengue clinical manifestations poses a challenge to predict the progression of dengue infection into severe symptoms. Platelet indices (PI) are readily available laboratory parameters that mark the activity and quality of platelets. The purpose of this study is to investigate PI profile on pediatric DHF and the association with disease severity.

Methods: This is an analytical observational study with a cross-sectional design. Samples are obtained consecutively from secondary data of children diagnosed with DHF in Wangaya Regional Hospital.
Chi-square analysis was used to assess the association between groups of platelet indices; mean platelet volume (MPV), platelet distribution width (PDW), platelet large cell ratio (P-LCR), and plateletcrit (PCT) with severity parameter, namely; DHF grade, length of hospitalization, shock, and bleeding.

Results: 150 subjects were included in the study. Bivariate analysis shows that MPV, PDW, and P-LCR does not correlate with any of the severity parameters. There is a significant correlation between $\mathrm{PCT}$ with the length of hospitalization $(p=<0.001)$, shock $(p=<0.001)$, and DHF grade $(p=<0.001)$. PCT does not correlate with bleeding.

Conclusion: There is a significant association between PCT PI and several parameters of DHF severity. PCT can be considered to predict DHF grade, length of hospitalization, and shock.

Keywords: platelet indices, dengue hemorrhagic fever, dengue shock syndrome.

Cite This Article: Wilhelmina, V.M., Suryawan, I.W.B., Suarca, K. 2021. Hubungan indeks platelet dengan derajat keparahan penyakit demam berdarah dengue pada anak di RSUD Wangaya. Intisari Sains Medis 12(2): 635-639. DOl: 10.15562/ism.v12i2.992

${ }^{1}$ General Practitioner-Intern, Department of Pediatrics Wangaya Regional Hospital Denpasar, Bali, Indonesia;

2Pediatrician, Department of Pediatrics Wangaya Regional Hospital Denpasar, Bali, Indonesia;

\section{*Korespondensi:}

Valerie Michaela Wilhelmina,

General Practitioner-Intern, Department of

Pediatrics Wangaya Regional Hospital Denpasar, Bali, Indonesia;

valeriemwr@gmail.com

Diterima: 06-03-2021

Disetujui: 18-08-2021

Diterbitkan: 31-08-2021

\title{
ABSTRAK
}

Latar belakang: Indonesia merupakan negara endemis Demam Berdarah Dengue (DBD). Lebih dari $80 \%$ anak usia $\geq 10$ tahun di Indonesia telah terinfeksi dengue setidaknya satu kali. Sindrom syok dengue (SSD) sebagai manifestasi klinis berat dari DBD memiliki resiko kematian yang tinggi. Spektrum manifestasi klinis yang luas menjadi tantangan untuk memprediksi DBD yang akan berujung menjadi gejala berat. Indeks platelet (IP) merupakan parameter laboratorium yang mudah didapat dan menggambarkan aktivitas dan kualitas platelet. Tujuan dari studi ini adalah untuk mempelajari profil IP pada penyakit DBD anak dan hubungannya terhadap derajat keparahan penyakit. Metode: Studi penelitian merupakan penelitian observasional analitik dengan desain potong lintang. Sampel diambil dari data sekunder pasien anak terdiagnosa DBD di unit rawat inap RSUD Wangaya dengan metode consecutive sampling. Analisis chisquare digunakan untuk menilai hubungan kelompok Indeks Platelet; mean platelet volume (MPV), platelet distribution width (PDW), platelet large cell ratio (P-LCR), dan plateletcrit (PCT) dengan parameter derajat keparahan yaitu grade DBD, lama rawat, syok, dan perdarahan.

Hasil: Sebanyak 150 subjek masuk dalam kriteria inklusi. Analisis bivariat menunjukkan MPV, PDW, dan PLCR tidak berhubungan dengan parameter derajat keparahan. Terdapat hasil signifikan PCT dengan lama rawat $(p=<0,001)$, syok $(p=<0,001)$, dan grade DBD $(p=<0,001)$. PCT tidak berhubungan dengan perdarahan.

Kesimpulan: Terdapat hubungan bermakna antara IP PCT dengan beberapa parameter derajat keparahan DBD. PCT dapat dipertimbangkan untuk memprediksi 
derajat keparahan penyakit yaitu grade DBD, lama rawat, dansyok.

Kata kunci: demam berdarah dengue, indeks platelet, sindrom syok dengue.

Sitasi Artikel ini: Wilhelmina, V.M., Suryawan, I.W.B., Suarca, K. 2021. Hubungan indeks platelet dengan derajat keparahan penyakit demam berdarah dengue pada anak di RSUD Wangaya. Intisari Sains Medis 12(2): 635-639. DOI: 10.15562/ism.v12i2.992

\section{PENDAHULUAN}

Dengue merupakan infeksi arbovirus yang disebarkan oleh vektor nyamuk Aedes aegypti dan albopictus dengan empat serotipe virus dengue (DENV) 1-4. Infeksi dengue menyebar secara cepat dengan jangkauan geografis semakin luas di dunia. Diperkirakan 2,5 miliar penduduk dunia pada lebih dari 125 negara endemik merupakan populasi berisiko. Secara global 50 juta infeksi dengue terjadi setiap tahunnya. ${ }^{1-3}$

Hingga kini infeksi dengue telah menjadi masalah kesehatan, terutama di Asia Tenggara yang sebagian besar negaranya mengalami siklus endemi. ${ }^{3}$ Indonesia merupakan negara tropis endemik dengan vektor dengue yang hampir dapat ditemukan di seluruh wilayahnya. ${ }^{4}$ Laju insidensi Demam Berdarah Dengue (DBD) di Indonesia tahun 2018 adalah 24,75 per 100.000 penduduk dan Case Fatality Rate (CFR) sebesar 0,71\%. Angka ini menurun dibandingkan tahun 2017 yaitu sebesar 26,10 per 100.000 penduduk dan CFR sebesar 0,72\%. ${ }^{5}$ Laju insidensi penyakit DBD di Provinsi Bali pada tahun 2018 juga mengalami penurunan secara signifikan yaitu 5 kali lipat dibanding tahun 2017 , yaitu sebesar 105,95 menjadi 21,6 per 100.000 penduduk. ${ }^{6}$ Dinas Kesehatan Kota Denpasar tahun 2018 melaporkan laju insidensi DBD sebesar 12,3 per 100.000 penduduk di Denpasar. ${ }^{7}$ Walaupun terdapat tren penurunan, infeksi dengue masih menjadi penyebab utama penyakit demam akut dan mengalami pola siklik dengan lonjakan insidensi yang memuncak per 6-8 tahun di Indonesia. ${ }^{4,8}$

Awalnya DBD banyak ditemukan dan menyebabkan kematian pada populasi anak dengan insidensi tertinggi pada usia 1-15 tahun. Namun semenjak tahun 1980 distribusi penyakit pada usia diatas 15 tahun meningkat. ${ }^{2}$ Studi mengenai seroprevalensi dengue pada populasi pediatri di Indonesia memaparkan lebih dari $80 \%$ anak usia $\geq 10$ tahun telah mengalami infeksi dengue setidaknya satu kali. Hal ini menunjukkan beban kesehatan penyakit yang tinggi pada anak di Indonesia. ${ }^{8}$

Infeksi dengue memiliki spektrum luas pada manifestasi klinis, dari subklinis hingga menimbulkan gejala ringan transien pada demam dengue, hingga derajat yang berpotensi mengancam jiwa pada DBD dan sindrom syok dengue (SSD). ${ }^{4,8}$

Sebanyak 500.000 kasus membutuhkan perawatan di rumah sakit dengan diagnosis DBD atau SSD dan terdapat sebanyak 20.000 kasus kematian. ${ }^{2}$ Salah satu yang masih menjadi tantangan hingga kini adalah membedakan pasien yang akan mengalami dengue ringan dengan pasien yang akan berujung mengalami dengue berat dengan komplikasi perburukan hingga syok dan kematian. Maka strategi sederhana dan efektif biaya untuk menilai parameter klinis atau laboratoris yang praktis dibutuhkan untuk manajemen kasus dengue, terutama dalam keadaan sumber daya fasilitas yang terbatas. ${ }^{9}$ Selain manifestasi klinis yang khas, trombositopenia merupakan salah satu temuan laboratoris utama pada DHF dan telah diasosiasikan dengan risiko progresifitas derajat keparahan penyakit dan mortalitas. ${ }^{8,9}$ Korelasi trombositopeni dengan klinis terjadinya gejala perdarahan dan kebocoran plasma masih bervariasi. ${ }^{8,10,11}$ Oleh karena itu, selain jumlah trombosit dapat diselidiki parameter lain yang lebih menggambarkan aktivitas dan kualitas platelet juga hubungannya dalam menilai perjalanan penyakit.

Indeks platelet (IP), antara lain mean platelet value (MPV), platelet distribution width (PDW), platelet large cell ratio (P-LCR), dan platelecrit (PCT) merupakan sekelompok parameter yang dapat menggambarkan aktivitas dan kualitas platelet dan mudah didapatkan sebagai bagian dari pemeriksaan darah rutin. Hingga saat ini, IP merupakan parameter yang kurang dimanfaatkan baik oleh personel laboratorium maupun dokter karena kurangnya standarisasi nilai referensi dan data mengenai aplikasi terhadap diagnosis yang terbatas. ${ }^{12}$ Penelitian ini bertujuan untuk mempelajari profil IP pada penyakit DBD serta asosiasi atau peran terhadap derajat keparahan penyakit.

\section{METODE}

Penelitian ini menggunakan rancangan observasional analitik dengan metode potong lintang dari data sekunder pasien anak terdiagnosa DBD di unit rawat inap RSUD Wangaya. Pengambilan sampel dilakukan secara metode consecutive sampling pada bulan Agustus - September 2020. Kriteria inklusi adalah pasien berusia $\leq 18$ tahun, telah didiagnosis sesuai kriteria klinis dan laboratoris demam berdarah dengue dan sindrom syok dengue berdasarkan WHO. Pasien yang pernah dirawat di unit rawat inap Kaswari dan ruang perawatan intensif bagian anak Rumah Sakit Umum Daerah Wangaya. Kriteria eksklusi adalah memiliki riwayat penyakit dengan manifestasi gangguan komponen trombosit, dan data rekam medis atau laboratoris tidak lengkap. Penelitian ini telah memperoleh kelaikan etik dari Komite Etik Penelitian Kesehatan RSUD Wangaya, Denpasar (No.051/VIII/ KEP/RSW/2020).

Dilakukan pengambilan data dari rekam medis yang meliputi karakteristik dasar subjek (usia dan jenis kelamin), parameter derajat keparahan (grade DBD, ada tidaknya manifestasi syok, perdarahan, dan lama rawat), dan data laboratoris fase kritis pada perjalanan penyakit hari ke 4-6 meliputi platelet dan komponen IP (MPV, PDW, PCT, P-LCR). 
Analisis data menggunakan program statistik SPSS ${ }^{\oplus}$ 26. Dilakukan analisis deskriptif (univariate) dan studi komparasi (bivariate) menggunakan uji chi-square $p$ value $<0,05$ dianggap signifikan.

\section{HASIL}

Sebanyak 150 subjek disertakan pada penelitian ini. Berdasarkan karakteristik jenis kelamin didapatkan bahwa jenis kelamin laki-laki lebih banyak dari perempuan. Rerata usia subjek dengan DBD adalah 10,5 tahun. Subjek paling banyak didapatkan pada kelompok usia 11-17 tahun dan paling sedikit pada kelompok usia 1-4 tahun. Berdasarkan penilaian derajat keparahan dengan manifestasi syok sebanyak 26,7\%, dan perdarahan sebanyak $22 \%$. Sedangkan berdasarkan grade, subjek yang mengalami SSD didapatkan sebanyak 26,6\%. Lama rawat $\geq 5$ hari didapatkan pada $32 \%$ subjek. Karakteristik umum dan klinis pasien tertera pada Tabel 1. Karakteristik laboratoris meliputi rerata dan simpang baku PLT, PDW, MPV, P-LCR, dan PCT tertera pada Tabel 2.

Analisis bivariat dilakukan untuk mengetahui hubungan antara IP dengan masing masing parameter derajat keparahan yaitu grade DBD, manifestasi syok, perdarahan, dan lama rawat. Analisis data tertera pada Tabel 3 dan 4 .

Hasil analisis chi-square antara variabel IP PCT dengan variabel lama rawat $\geq 5$ hari, dan syok menunjukan $p$ value $<0,05$ pada CI $=95 \%$. Sementara tidak terdapat hasil bermakna antara PCT dan variabel manifestasi perdarahan. Pada variabel IP lainnya PDW, MPV dan P-LCR terhadap tiap variabel derajat keparahan ditemukan $p$ value $>0,05$ pada $C I=95 \%$. Hasil analisis chi-square antara variabel IP dan grade DBD menunjukan $p$ value $<0,05$, $\mathrm{CI}=95 \%$ pada $\mathrm{PCT}$ dengan grade DBD.

\section{Tabel 1. Karakteristik umum dan klinis subjek penelitian}

\begin{tabular}{cc}
\hline Karakteristik & $\mathbf{n = 1 5 0}$ \\
Jenis Kelamin, $\mathrm{n}(\%)$ & $89(59,3)$ \\
Laki-laki & $61(40,7)$ \\
Perempuan & $10,5 \pm 4,5$ \\
Usia(tahun), mean \pm SD & \\
Usia(tahun), n (\%) & $16(10,7)$ \\
$1-4$ & $54(36,0)$ \\
$5-10$ & $80(53,3)$ \\
$11-17$ & \\
Grade DBD, n (\%) & $86(57,3)$ \\
Grade I & $24(16,0)$ \\
Grade II & $35(23,3)$ \\
Grade III & $5(3,3)$ \\
Grade IV & $40(26,7)$ \\
Syok, $\mathrm{n}(\%)$ & $33(22,0)$ \\
Perdarahan, $\mathrm{n}(\%)$ & $5,2 \pm 1,4$ \\
Lama rawat (hari), mean \pm SD & \\
$\geq 5$ hari & $48(32)$ \\
$<5$ hari & $102(68)$ \\
\hline
\end{tabular}

Tabel 2. Karakteristik laboratoris subjek penelitian

\begin{tabular}{cc}
\hline Karakteristik Laboratoris & $\mathbf{n = 1 5 0}$ \\
\hline PLT $\left(10^{3} /\right.$ ul), mean \pm SD & $70,8 \pm 31,25$ \\
PDW $(\mathrm{fl})$, mean \pm SD & $13,7 \pm 2,42$ \\
MPV (fl), mean \pm SD & $11,1 \pm 0,99$ \\
P-LCR (\%), mean \pm SD & $33,8 \pm 6,92$ \\
PCT (\%), mean \pm SD & $0,7 \pm 0,03$
\end{tabular}

Pada rerata nilai peningkatan PCT $\geq 0,07$ ditemukan rerata yang lebih rendah pada kelompok SSD.

Trombositopenia pada infeksi dengue dapat disebabkan oleh supresi aktivitas

\section{PEMBAHASAN}

\section{Tabel 3. Hubungan Indeks Platelet terhadap lama rawat, perdarahan dan syok}

\begin{tabular}{|c|c|c|c|c|c|c|}
\hline & \multicolumn{2}{|c|}{ Lama Rawat } & \multicolumn{2}{|c|}{ Pendarahan } & \multicolumn{2}{|c|}{ Syok } \\
\hline & n (\%) & p & n (\%) & p & n (\%) & $\mathbf{p}$ \\
\hline \multicolumn{7}{|l|}{ PDW } \\
\hline$<13,74$ & $48(32)$ & \multirow{3}{*}{0,153} & $17(11,3)$ & \multirow{3}{*}{0,881} & $17(11,3)$ & \multirow[t]{3}{*}{0,133} \\
\hline$\geq 13,74$ & $51(34)$ & & $16(10,7)$ & & $23(15,3)$ & \\
\hline MPV & & & & & & \\
\hline$<11,06$ & $27(18)$ & \multirow{3}{*}{0,385} & $17(11,3)$ & \multirow{2}{*}{0,647} & $19(12,7)$ & \multirow{2}{*}{0,941} \\
\hline$\geq 11,06$ & $54(36)$ & & $16(10,7)$ & & $21(14)$ & \\
\hline P-LCR & & & & & & \\
\hline$<33,75$ & $48(32)$ & \multirow{2}{*}{0,722} & $17(11,3)$ & \multirow{2}{*}{0,777} & $20(13,3)$ & \multirow{2}{*}{0,922} \\
\hline$\geq 33,75$ & $51(34)$ & & $16(10,7)$ & & $20(13,3)$ & \\
\hline PCT & & & & & & \\
\hline$<0,07$ & $57(38)$ & \multirow{2}{*}{${ }^{*}<0,001$} & $13(8,7)$ & \multirow{2}{*}{0,301} & $32(21,3)$ & \multirow{2}{*}{$*<0,00$} \\
\hline$\geq 0,07$ & $42(28)$ & & $20(13,3)$ & & $8(5,3)$ & \\
\hline
\end{tabular}


Tabel 4. Hubungan indeks platelet terhadap grade DBD

\begin{tabular}{cccccc}
\hline \multicolumn{5}{c}{ DHF grade, $\mathbf{n}(\%)$} \\
\cline { 2 - 6 } & DHF grade I & DHF grade II & DHF grade III & DHF grade IV & p \\
\hline PDW & & & & \\
$<13,74$ & $50(33,3)$ & $12(8)$ & $15(10)$ & $2(1,3)$ & 0,428 \\
$\geq 13,74$ & $36(24)$ & $12(8)$ & $20(13,3)$ & $3(2)$ & \\
MPV & & & & $3(2)$ & 0,849 \\
$<11,06$ & $40(26,6)$ & $13(8,6)$ & $16(10,6)$ & $2(1,3)$ & \\
$\geq 11,06$ & $46(30,6)$ & $11(7,3)$ & $19(12,6)$ & & \\
P-LCR & & & & $4(2,6)$ & \\
$<33,75$ & $77(51,3)$ & $21(14)$ & $33(22)$ & $1(0,6)$ & \\
$\geq 33,75$ & $9(6)$ & $3(2)$ & $2(1,3)$ & & \\
PCT & & & & $5(3,3)$ & $<0,001$ \\
$<0,07$ & $32(21,3)$ & $7(4,6)$ & $27(18)$ & $0(0)$ & \\
$\geq 0,07$ & $54(36)$ & $17(11,3)$ & $8(5,3)$ & \\
\hline
\end{tabular}

hematopoesis sumsum tulang, atau destruksi platelet perifer yang disebabkan oleh fungsi platelet yang terganggu. ${ }^{13}$ Trombositopenia berkaitan dengan risiko vaskulopati yang dapat menyebabkan perdarahan dan kebocoran plasma. Pasien dengan trombositopenia berat sehingga memerlukan transfusi dapat berdampak terhadap peningkatan lama rawat dan risiko edema paru. ${ }^{14}$

IP menggambarkan morfologi platelet dan dapat menjadi penanda sugestif yang menunjukkan penyebab trombositopenia yang disebabkan oleh aktivitas sumsum tulang atau destruksi platelet yang sedang berlangsung..$^{13}$ Pada penelitian ini didapatkan penurunan pada rerata nilai PCT dari rentang batas normal populasi $(0,07)$. PCT adalah biomassa platelet dalam darah perifer. ${ }^{15}$ PCT merupakan produk dari perhitungan jumlah dan volume platelet dengan rumus $\mathrm{PCT}=$ PLT $\mathrm{X}$ MPV/100.000. ${ }^{16}$ Dalam keadaan fisiologis jumlah platelet akan dijaga dalam jumlah seimbang melalui regenerasi dan eliminasi agar masa platelet tetap konstan. ${ }^{17}$ Trombositopenia disertai penurunan PCT mengindikasikan konsumsi platelet yang meningkat. Penelitian diagnostik oleh Prameswari dkk. mendapatkan pada nilai PCT $<0,14$ memiliki risiko mengalami syok 9,52 dengan sensitivitas $94,44 \%$ dan spesifisitas $61,9 \%{ }^{18}$ Hal ini sesuai dengan temuan penelitian ini yaitu pada kelompok PCT $<0,07$ memiliki hubungan signifikan dengan syok. Penelitian oleh Ciranth SB dkk menyatakan bahwa nilai PCT yang rendah memiliki hubungan terhadap kelompok derajat penyakit yang lebih berat dan pendarahan. ${ }^{13}$ Pada penelitian ini tidak ditemukan hubungan PCT terhadap pendarahan. Sementara PCT memiliki hubungan signifikan terhadap grade DBD. Penelitian oleh Nehara dkk. membandingkan kelompok (DD) dengan DBD. PCT yang rendah memiliki sensitifitas yang lebih tinggi pada kelompok DBD dibandingkan DD dan memiliki spesifisitas yang serupa antar kedua kelompok. PCT dan P-LCR juga memiliki korelasi positif yang sangat kuat terhadap rerata jumlah trombosit dibandingkan parameter IP lainnya (MPV, PDW) ${ }^{19}$

MPV menunjukkan ukuran platelet dalam sirkulasi, PDW mengukur variabilitas ukuran platelet, sedangkan P-LCR menggambarkan persentase platelet yang melampaui ukuran normal di dalam peredaran darah. ${ }^{20}$ Nilai P-LCR berbanding terbalik dengan jumlah trombosit namun memiliki hubungan linear terhadap MPV dan PDW. ${ }^{21}$ Pada penelitian ini rerata nilai MPV, PDW dan P-LCR terdapat dalam rentang batas normal dengan sebagian besar nilai cenderung meningkat dari rerata. Sesuai dengan temuan Khatri dkk. yaitu nilai MPV, PDW dalam batas normal dan PCT menurun. ${ }^{15}$ Pada penelitian oleh Sharma K dkk. dan Dewi YP dkk. Nilai MPV juga ditemukan dalam batas normal dan tidak ditemukan korelasi bermakna antara MPV jumlah trombosit, perdarahan, dan tingkatan infeksi dengue. ${ }^{22,23}$ MPV tidak ditemukan sebagai parameter prognostik penting pada kasus infeksi dengue.22 Namun beberapa penelitian mendapat hasil sebaliknya yaitu MPV menurun dan PDW yang meningkat pada infeksi dengue. ${ }^{19,21,24}$

Penelitian Ciranth S.B dkk. menyatakan bahwa MPV dan PDW yang rendah tidak memiliki efek terhadap derajat keparahan penyakit. $^{13}$ Namun pada populasi penelitian dengan nilai PDW yang meningkat memiliki parameter derajat keparahan yang lebih berat. Nehara dkk. mengatakan trombosit, MPV dan PCT yang menurun, PDW dan P-LCR yang meningkat memiliki sensitivitas, spesifisitas bermakna pada DBD dan dapat digunakan sebagai prediktor infeksi dengue. ${ }^{19}$ Bashir dkk. mendapatkan temuan serupa yaitu nilai MPV rendah, PDW dan P-LCR tinggi namun sensitivitas, spesifisitas dan nilai prediksi positif lebih besar pada DD dibandingkan DBD. ${ }^{21}$ Walaupun demikian hal tersebut tidak ditemukan pada penelitian ini; nilai MPV, PDW, dan P-LCR menunjukkan kecenderungan linear.

Peningkatan nilai MPV menandakan aktivasi platelet yang meningkat, destruksi perifer platelet, dan hiperaktivitas megakariosit. Sebaliknya penurunan nilai MPV menggambarkan supresi sumsum tulang dan berhubungan dengan peningkatan risiko perdarahan. Peningkatan nilai PDW didapatkan lebih besar pada trombositopenia yang disebabkan oleh hiperdestruksi perifer dibandingkan hipoproduksi oleh sumsum tulang. Hiperdestruksi platelet menyebabkan kompensasi sumsum tulang yang memproduksi platelet imatur yang berukuran lebih besar sehingga menyebabkan peningkatan nilai PDW. $^{16,17}$ Pada penelitian Ciranth SB dkk. PDW meningkat ditemukan pada fase perbaikan. ${ }^{13}$ Pada penelitian ini data laboratoris diambil pada fase kritis hari 4-6 sehingga kemungkinan belum terlihat variasi yang diakibatkan dari kompensasi terhadap trombositopenia yang bermakna pada IP selain PCT.

\section{SIMPULAN}

Terdapat hubungan antara IP PCT dengan beberapa parameter derajat keparahan penyakit DBD yaitu grade DBD, lama rawat, dan syok. Tidak ada IP yang memiliki hubungan dengan manifestasi perdarahan. 


\section{ETIKA PENELITIAN}

Penelitian ini telah memenuhi syarat kelaikan etik dari Komite Etik Penelitian Kesehatan RSUD Wangaya, Denpasar (No.051/VIII/KEP/RSW/2020).

\section{KONFLIK KEPENTINGAN}

Peneliti menyatakan tidak terdapat konflik kepentingan dalam studi ini.

\section{PENDANAAN}

Peneliti tidak mendapatkan hibah, sponsor atau sumber pendanaan publik, organisasi non-profit, ataupun komersil.

\section{KONTRIBUSI PENULIS}

Penulis berkontribusi terhadap penelitian ini baik dari perencanaan hingga interpretasi dan penyusunan naskah publikasi.

\section{DAFTAR PUSTAKA}

1. Ferreira GL. Global dengue epidemiology trends. Rev Inst Med Trop Sao Paulo. 2012;54 Suppl 18:S5-S6. doi:10.1590/s003646652012000700003.

2. Karyanti MR, Uiterwaal CS, Kusriastuti $\mathrm{R}$, et al. The changing incidence of dengue haemorrhagic fever in Indonesia: a 45-year registry-based analysis. BMC Infect Dis. 2014;14:412. doi:10.1186/1471-2334-14-412.

3. Bhatia R, Dash AP, Sunyoto T. Changing epidemiology of dengue in South-East Asia. WHO South East Asia J Public Health. 2013;2(1):23-27. doi:10.4103/22243151.115830

4. Harapan H, Michie A, Mudatsir M, Sasmono RT, Imrie A. Epidemiology of dengue hemorrhagic fever in Indonesia: analysis of five decades data from the National Disease Surveillance. BMC Res Notes. 2019;12(1):350. doi:10.1186/s13104019-4379-9.
5. Kementrian Kesehatan RI. Profil Kesehatan Indonesia Tahun 2018 Jakarta: 2018.

6. Dinas Kesehatan Provinsi Bali. Profil Kesehatan Provinsi Bali 2018. Denpasar: 2018;

7. Dinas Kesehatan Kota Denpasar. Profil Dinas Kesehatan Kota Denpasar Tahun 2018. Denpasar: 2018.

8. Utama IMS, Lukman N, Sukmawati DD, et al. Dengue viral infection in Indonesia: Epidemiology, diagnostic challenges, and mutations from an observational cohort study. PLoS Negl Trop Dis. 2019;13(10):e0007785. doi:10.1371/journal.pntd.0007785.

9. Prayitno A, Taurel AF, Nealon J, et al. Dengue seroprevalence and force of primary infection in a representative population of urban dwelling Indonesian children [published correction appears in PLoS Negl Trop Dis. 2018 May 2;12 (5):e0006467]. PLoS Negl Trop Dis. 2017;11(6):e0005621. doi:10.1371/journal. pntd.0005621.

10. Yacoub S, Wills B. Predicting outcome from dengue. BMC Med. 2014;12:147. Published 2014 Sep 4. doi:10.1186/s12916-014-0147-9.

11. WHO. Comprehensive guidelines for prevention and control of dengue and dengue haemorrhagic fever. WHO Regional Publication SEARO. 2011. p159-168.

12. Giovanetti TV, do Nascimento AJ, de Paula JP. Platelet indices: laboratory and clinical applications. Rev Bras Hematol Hemoter. 2011;33(2):164-165. doi:10.5581/15168484.20110040

13. Chiranth, SB, Avabratha KS. Platelet Indices and the Severity of Dengue Infection in Children. J Pediatr Res. 2019;6(3):242-6. doi: 10.4274/jpr. galenos.2019.47568.

14. de Azeredo EL, Monteiro RQ, de-Oliveira Pinto LM. Thrombocytopenia in Dengue: Interrelationship between Virus and the Imbalance between Coagulation and Fibrinolysis and Inflammatory Mediators. Mediators Inflamm. 2015;2015:313842. doi:10.1155/2015/313842.

15. Khatri S, Sabeena S, Arunkumar G, Mathew M. Utility of Platelet Parameters in Serologically Proven Dengue Cases with Thrombocytopenia. Indian J Hematol Blood Transfus. 2018;34(4):703-706. doi:10.1007/s12288-0180924-2.
16. Kantharaj A. Role of red cell and platelet indices as a predictive tool for transfusions in dengue. Glob J Transfus Med. 2018;3(2):103. doi:10.4103/GJTM.GJTM_39_18.

17. Zhang S, Cui YL, Diao MY, Chen DC, Lin ZF. Use of Platelet Indices for Determining Illness Severity and Predicting Prognosis in Critically Ill Patients. Chin Med J (Engl). 2015;128(15):2012-2018. doi:10.4103/03666999.161346.

18. Prameswari A, Iskandar A, Wafi M. Jumlah Rerata Trombosit Dan Plateletcrit (MPV dan PCT) Sebagai Prediktor Syok pada Anak yang Terinfeksi Dengue di RS Dr. Saiful Anwar Malang. Maj Kesehat. 2018;5(3):153-9. doi: 10.21776/ub.majalahkesehatan.005.03.4.

19. Gupta BK, Nehara HR, Meena SL, Parmar S. Evaluation of Platelet Indices in Patients With Dengue Infections. Int J Sci Res. 2016;5(7):7881. doi: $10.36106 /$ ijsr.

20. Pogorzelska K, Krętowska A, Krawczuk-Rybak M, Sawicka-Żukowska M. Characteristics of platelet indices and their prognostic significance in selected medical condition - a systematic review. Adv Med Sci. 2020;65(2):310-315. doi:10.1016/j.advms.2020.05.002.

21. Bashir AB, Saeed OK, Mohammed BA, Ageep AK. Role of Platelet Indices in Patients with Dengue Infection in Red Sea State, Sudan. IJSR. Volume 4 Issue 1. 2015. p1573 - 1576.

22. Sharma K, Yadav A. Association of Mean Platelet Volume with Severity, Serology \& Treatment Outcome in Dengue Fever: Prognostic Utility. J Clin Diagn Res. 2015;9(11):EC01-EC3. doi:10.7860/JCDR/2015/14285.6710.

23. Dewi YP, Laksanawati IS, Arguni E, Indrawanti R. Mean Platelet Volume (MPV): potential predictor of disease severity in Dengue infection. Int Dengue Symp 2013. 2014. p4-72.

24. Vyas N, Nair S, Rao M, Miraj SS. Childhood Obesity and Diabetes: Role of Probiotics and Prebiotics. In: Global Perspectives on Childhood Obesity. 2019.

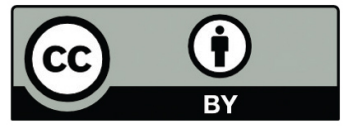

This work is licensed under a Creative Commons Attribution 